Policy Research Working Paper 2219

The Effect of the United States' Granting Most Favored Nation Status to Vietnam

\section{Emiko Fukase}

Will Martin
If the United States grants

Vietnam most favored nation status, both countries would benefit: Vietnamese exports to the United States would more than double, and Vietnam would gain substantial welfare benefits from improved market access and increased availability of imports. For the United States, lowering the current high tariffs against Vietnam would improve welfare by reducing costly diversion away from Vietnamese products.

The World Bank

Development Research Group

Trade

November 1999 
Policy Research Working Paper 2219

\section{Summary findings}

Since the U.S. embargo on trade with Vietnam was lifted in 1994, exports from Vietnam to the United States have risen dramatically. However, Vietnam remains one of the few countries to which the United States has not yet granted most favored nation (MFN) status. The general tariff rates that the United States imposes average 35 percent compared with 4.9 percent for the MFN rate.

Granting MFN status to Vietnam would improve its terms of trade and help improve the efficiency of resource allocation in the country. Better access to the U.S. market would increase the volume of Viecnamese exports to the United States and the prices received for them while also reducing their costs to U.S. users.

Fukase and Martin use a computable general equilibrium model to examine the effects of reducing U.S. tariffs on Vietnamese imports from general rates to MFN rates. They estimate tariff changes using the U.S. tariff schedule for 1997 weighted by Vietnam's exports to the United States.

The results suggest that after a change to MFN status for Vietnam, its exports to the United States would more than double, from the 1996 baseline of $\$ 338$ million to $\$ 768$ million. By conservative estimates, welfare gains in Vietnam would be about $\$ 118$ million a year, or a 0.9 percent increase in real income per capita. Sixty percent of that gain would come from improved terms of trade and the other 40 percent from gains in efficiency. Because Vietnam's exports to the United States have been growing rapidly since the lifting of the embargo in 1994, the trade expansion resulting from MFN status may be larger by the time Vietnam obtains it. Based on 1998 values, the increase in exports would have been around S750 million a year.

For the United States, lowering the high tariffs on imports from Vietnam would improve consumer welfare by lowering prices and increasing the volume of those imports. The direct welfare gains in the United States are estimated to be $\$ 56$ million a year.

There are likely to be significant additional gains to both countries from the liberalization Vietnam will undertake as a result of the negotiations for MFN status and for entry into the World Trade Organization.

This paper - a product of Trade, Development Research Group - is part of a larger effort in the group to understand the links between trade and development in transition economies. Copies of the paper are available free from the World Bank, 1818 H Street NW, Washington, DC 20433. Please contact Lili Tabada, room MC3-333, telephone 202-473-6896, fax 202-522-1159, Internet address Itabada@worldbank.org. Policy Research Working Papers are also posted on the Web at http://www.worldbank.org/research/working papers. The authors may be contacted at efukase@worldbank.org or wmartin1@worldbank.org. November 1999. 26 pages)

The Policy Research Working Paper Series disseninates the findings of work in progress to encourage the exchange of ideas about development issues. An objective of the series is to get the findings out quickly, even if the presentations are less than fully polished. The papers carry the names of the authors and should be cited accordingly. The findings, interpretations, and conclusions expressed in this paper are entirely those of the authors. They do not necessarily retresent the view of the World Bank, its Executive Directors, or the countries they represent. 


\title{
The Effect of the United States' Granting Most Favored Nation Status to Vietnam ${ }^{1}$
}

by

\author{
Emiko Fukase and Will Martin \\ Development Research Group
}

World Bank

Washington, DC, USA

\footnotetext{
${ }^{1}$ We would like to thank Kazi Matin for the initiation and support of this research; participants in the trade workshops in Hanoi and Ho Chi Minh City in April 1999 for helpful discussions and comments; and Hugh Arce for supplying the very useful tariff data.
} 



\section{Summary findings}

Since the lifting of the United States' embargo on trade with Vietnam, exports from Vietnam to the U.S. have risen dramatically. However, Vietnam remains one of a handful countries to which the United States has not yet granted Most-Favored-Nation (MFN) status, and on which it imposes its general tariffs rather than the more widely used MFN tariffs. The general rates are typically much higher than the MFN rates with the simple-average of 35.0 percent as against 4.9 percent for the MFN rate.

The US granting MFN status to Vietnam gives Vietnam economic benefits from two sources: 1) improved terms of trade and 2) second-best welfare benefits from improved allocative efficiency. The improved market access to the United States leads to an increase in both the volume of exports from Vietnam to the United States, and an increase in the price received for these exports. Given the extensive distortions inherent in Vietnam's current trade regime, there are likely to be other welfare changes resulting from increases in the volume of exports, and the consequent increase in imports over Vietnam's sizable import tariffs.

We use a computable general equilibrium model to examine the consequences of the U.S. reducing its tariffs against imports from Vietnam from general rates to the MFN level. The tariff changes were estimated by using the U.S. Tariff schedule for 1997 weighted by Vietnam's exports to the United States.

The results suggest that Vietnam's exports to the United States more than double following the move to MFN status, from the 1996 baseline level of $\$ 337.5$ million to 
$\$ 767.5$ million. ${ }^{2}$ The increase in exports of clothing is particularly significant, registering almost a fifteen-fold increase relative to the baseline. The MFN access to the United States creates substantial welfare benefits to Vietnam. The welfare gains to Vietnam are very conservatively estimated at around $\$ 118$ million per year or 0.9 percent increase in real expenditure per capita. The direct terms of trade improvement resulting from increased market access accounts for 60 percent of the total gain, with the remaining 40 percent derived from induced second-best gains in efficiency.

From the point of view of the United States, this exercise involves unwinding the trade diversion away from Vietnamese imports resulting from the higher tariff rate against imports from Vietnam. The lowering of these high tariffs raises consumer welfare by lowering prices, and the dramatic increases in imports from Vietnam induce generate welfare benefits that accrue as tariff: revenues. Despite this, the direct benefits to the USA of granting MFN treatment to Vietnam are relatively small at $\$ 56$ million per year. This study focuses on the direct impacts of US liberalization. In addition, there are likely to be significant gains to both Vietnam and the United States from the liberalization that Vietnam agrees to undertake in the ongoing negotiations for MFN access and entry to the World Trade Organization.

\footnotetext{
${ }^{2}$ As Vietnam's exports to the United States have been growing rapidly since the lifting of the embargo in 1994, the magnitude of the trade-expansion resulting from MFN status may be larger by the time Vietnam obtains MFN. Based on 1998 values, the increase in exports would have been around $\$ 750$ million per year.
} 


\section{The Effect of the United States Granting MFN Status to Vietnam}

\section{Introduction}

Since the lifting of the U.S. embargo in 1994, trade between Vietnam and the United States has grown rapidly. The large U.S. market offers substantial potential for Vietnam to expand its exports, following the lead of the export-oriented economies of its region. However, Vietnam remains one of a handful countries to which the United States has not yet granted Most-Favored-Nation (MFN) status, and on which it imposes its general tariffs rather than the more widely used MFN tariffs.

The general tariff schedule involves much higher tariff rates on most commodities than the MFN schedule. Use of these tariffs clearly imposes costs on both Vietnam and the United States. Vietnamese exporters are unable to access the best markets for some of their products. US imports are diverted from lower cost suppliers in Vietnam to higher cost sources elsewhere.

The objective of this paper is to assess the economic effects of the U.S. granting MFN status to Vietnam. We first assess the size of the trade distortions involved, and then analyze their consequences. Section II deals with the pattern of exports from Vietnam to the United States and the nature of the barriers imposed by use of the general tariffs. Section III describes the analytical framework and presents results and interpretation. Section IV presents the main conclusions.

\section{Recent Trends in Vietnam's Exports to the United States}

\section{Composition of Vietnam's Exports to the United States}

Since 1994, Vietnam's merchandise exports to the United States have increased rapidly, from $\$ 54.0$ million in 1994 , to $\$ 207.8$ million in 1995 , and $\$ 337.5$ million in 
1996. In 1997 and in 1998 , Vietnam's exports to the U.S. accounted for $\$ 407.1$ million and \$588.7 million respectively (U.N. Comtrade System, 1994-1998). In $1996,{ }^{3} 4.8$ percent of Vietnam's exports were shipped to the U.S., which in turn accounted for 0.04 percent of total U.S. imports (World Bank, 1998a). Figure 1 shows the evolution of Vietnam's exports to the U.S. by commodities for the years 1994 to $1998 .^{4}$ The exports by GTAP category are shown in Arnex 1.

Figure 1 - Vietnam's Exports to the U.S. 1994-1998

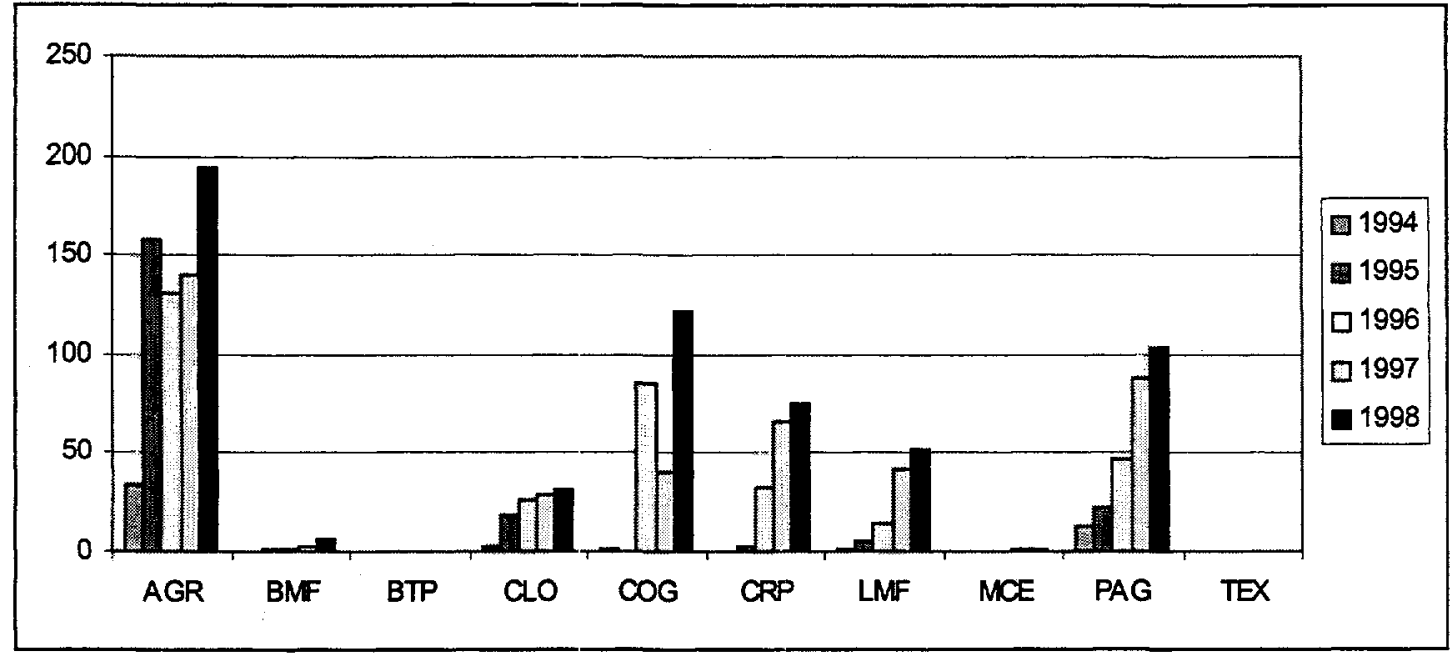

Source: U.N. Comtrade System

In 1994 and 1995, agriculture and forestry (ARG), processed agriculture (PAG), and closing (CLO) dominated Vietnam's exports to the U.S. In 1996, exports of

\footnotetext{
${ }^{3}$ The data for the year 1996 are analyzed in some details in this paper since our simulation results are based on the 1996 data.

${ }^{4}$ The model database was aggregated from the original 50 sectors to twelve sectors designed to provide a reasonable representation of Vietnam's trade patterns: agriculture and forestry (AGR), basic manufacturing (BMF), beverages and tobacco products (BTP), clothing (CLO), chemical, rubber, plastic products (CRP), coal, oil, gas (COG), light manufacturing (LMF), electronics and machinery (MCE), processed agricultural commodities (PAG), petroleum and coal products (PCP), textiles (TEX), transport equipment (TRP), and others (OTH). This aggregation contains nonzero values for all exports to the United States except refined petroleum and coal products, and transportation equipment. Neither of these products seems likely to become a major export from Vietnam to the United States in the new future, so setting them to zero seems unlikely to be a serious problem. Annex 3 presents the description of the aggregation.
} 
petroleum oils (COG), chemical, rubber, plastic products (CRP) ${ }^{5}$, and light manufacturing (LMF) emerged, giving Vietnam a much more diversified pattern of exports to the United States. Further increase in exports of chemical, rubber, plastic products (CRP) and light manufacturing (LMF) in 1997 and 1998 is mainly attributed to the footwear exports.

Annex 3 A-E presents the top 10 export commodities from Vietnam to U.S. according to 6-digit Harmonized System (HS) categories for the years 1994-1998. The top 10 commodities accounted for 91.3 percent of Vietnam's exports to the U.S. in 1994, 92.7 percent in $1995,87.0$ percent in $1996,73.8$ percent in 1997 , and 84.3 percent in 1998. Coffee has been the leading exports throughout the period 1994-1998. In 1996, exports of 'petroleum oils' emerged, accounting for a quarter of Vietnam's total exports. The other leading export commodities included shrimps, rice, cashew nuts, clothing, footwear, and gloves.

\section{MFN and Non-MFN Tariff Analyses}

The United States generally applies the MFN rate in the U.S. tariff schedule to almost all of its WTO and non-WTO trading partners. ${ }^{6}$ Countries not receiving U.S. MFN status are subject to the higher general rates. These rates are for the most part the original statutory rates that were applied to all U.S. imports under the Tariff Act of 1930 (also known as the Smoot-Hawley Act). After the trade liberalization of the various

\footnotetext{
${ }^{5}$ Vietnam's main export item to the U.S. in this category is casual footwear using rubber.

${ }^{6}$ As of June 1998, all countries except Afghanistan, Cuba, the Lao PDR, Monenegro, North Korea, Serbia, and Vietnam have MFN status. Albania, Armenia, Belarus, Bulgaria, China, Georgia, Kazakhstan, Kyrgyzstan, Moldova, Mongolia, Romania, Russia, Tajikistan, Turkmenistan, Ukraine and Uzbekistan all have their MFN status reviewed annually (Personal communication, the Trade Information Center, the U.S. Department of Commerce).
} 
GATT Rounds beginning in 1947, the Unites States retained the general rates primarily against Communist countries (Arce and Taylor, 1997).

Table 2 compares estimates of the MFN and non-MFN tariff rates levied on

\author{
Vietnam.
}

Table 2 - U.S. Tariffs against Vietnam's Exports MFN vs Non-MFN Rates

\begin{tabular}{|c|c|c|c|c|c|c|c|c|c|}
\hline \multirow[b]{3}{*}{ GTAP } & \multirow[b]{3}{*}{ Description } & \multicolumn{2}{|c|}{$\begin{array}{c}\text { SIMPLE } \\
\text { AVERAGE (\%) }\end{array}$} & \multicolumn{6}{|c|}{$\begin{array}{c}\text { WEIGHTED } \\
\text { AVERAGE }(\%)\end{array}$} \\
\hline & & \multirow[b]{2}{*}{$\underline{\text { MFI }}$} & \multirow[b]{2}{*}{$\frac{\text { Non- }}{\text { MFN }}$} & \multicolumn{2}{|c|}{$\begin{array}{c}1994 \text { Import } \\
\text { Weights }\end{array}$} & \multicolumn{2}{|c|}{$\begin{array}{c}1995 \text { Import } \\
\text { Weights }\end{array}$} & \multicolumn{2}{|c|}{$\begin{array}{c}1996 \text { Import } \\
\text { Weights }\end{array}$} \\
\hline & & & & MFN & $\begin{array}{l}\text { Non- } \\
\text { MFN }\end{array}$ & MFN & Non- & MFN & Non- \\
\hline 1 & Paddy rice & 1.7 & $\overline{6.5}$ & na & na & na & $\overline{\text { na }}$ & na & na \\
\hline 2 & Wheat & 3.5 & 10.0 & na & na & na & na & na & na \\
\hline 3 & Cereal grains & 0.6 & 4.0 & na & na & na & na & 1.4 & 3.6 \\
\hline 4 & Vegetables, fruits, nuts & 5.4 & 20.8 & 0.2 & 1.8 & 0.3 & 2.9 & 0.1 & 1.2 \\
\hline 5 & Oil seeds & 8.2 & 35.4 & 0.0 & 1.6 & na & na & 0.0 & 0.0 \\
\hline 6 & Sugar cane, sugar beet & 2.1 & na* & na & na & na & na & 2.5 & na* \\
\hline 7 & Plant-based fibers & 0.3 & 1.6 & na & na & na & na & 0.0 & 0.0 \\
\hline 8 & Crops n.e.e. & 2.8 & 18.2 & 0.0 & 0.0 & 0.0 & 0.0 & 0.0 & 0.0 \\
\hline 9 & Bovine cattle, sheep, goats, horses & 0.7 & 7.8 & na & na & na & na & na & na \\
\hline 10 & Animal products n.e.c. & 1.2 & 5.6 & 3.1 & 12.4 & 2.5 & 14.2 & 1.5 & 11.1 \\
\hline 12 & Wool, silk-worm cocoons & 0.6 & 0.0 & na & na & na & na & na & na \\
\hline 13 & Forestry & 0.0 & 1.7 & na & na & na & na & 0.0 & 0.0 \\
\hline 14 & Fishing & 0.4 & 3.9 & 0.0 & 0.0 & 0.2 & 4.2 & 0.0 & 0.0 \\
\hline 15 & Coal & 0.0 & 0.0 & 0.0 & 0.0 & na & na & na & na \\
\hline 16 & Oil & 0.2 & 0.6 & na & na & na & na & 0.4 & 1.3 \\
\hline 17 & Gas & 0.0 & 0.0 & na & na & na & na & na & na \\
\hline 18 & Minerals n.e.c. & 0.7 & 10.0 & 3.4 & 7.5 & 1.1 & 10.0 & 1.3 & 10.3 \\
\hline 19 & Bovine cattle, sheep, goat, horse meat & 3.4 & 23.9 & na & na & na & na & na & na \\
\hline 20 & Meat products n.e.c. & 4.7 & 23.1 & na & na & na & na & na & na \\
\hline 21 & Vegetable oils and fats & 3.7 & 12.8 & 0.0 & $\mathrm{na}^{*}$ & na & na & na & na \\
\hline 22 & Dairy products & 27.3 & 29.9 & na & na & na & na & na & na \\
\hline 23 & Processed rice & 5.8 & 23.6 & 8.8 & 35.0 & 8.8 & 35.0 & 8.8 & 35.0 \\
\hline 24 & Sugar & 10.3 & 20.0 & na & na & na & na & na & na \\
\hline 25 & Food products n.e.c. & 5.5 & 19.2 & 0.3 & 1.1 & 0.3 & 1.3 & 0.5 & 1.9 \\
\hline 26 & Beverage and tobacco products & 16.8 & 92.0 & 2.8 & 18.1 & 4.5 & 22.1 & 2.2 & 17.4 \\
\hline 27 & Textiles & 10.3 & 55.1 & 6.7 & 63.8 & 9.6 & 58.2 & 4.4 & 38.5 \\
\hline 28 & Wearing apparel & 13.4 & 68.9 & 13.5 & 56.4 & 13.1 & 52.5 & 14.3 & 58.0 \\
\hline 29 & Leather products & 5.6 & 33.0 & 11.9 & 46.3 & 9.2 & 28.4 & 8.4 & 22.8 \\
\hline 30 & Wood products & 2.1 & 29.4 & 3.3 & 38.7 & 3.5 & 38.9 & 3.5 & 37.3 \\
\hline 31 & Paper products, publishing & 1.3 & 22.7 & 0.9 & 21.9 & 0.3 & 4.1 & 1.6 & 25.4 \\
\hline 32 & Petroleum, coal products & 1.3 & 8.6 & na & na & 0.0 & 4.3 & na & na \\
\hline 33 & Chemical, rubber, plastic, products & 4.3 & 30.3 & 5.3 & 24.5 & 6.4 & 25.1 & 30.8 & 49.6 \\
\hline 34 & Mineral products n.e.c. & 4.3 & 41.6 & 4.1 & 42.4 & 3.6 & 40.2 & 3.8 & 40.4 \\
\hline 35 & Ferrous metals & 3.7 & 21.5 & na & na & na & na & na & na \\
\hline 36 & Metals n.e.c. & 3.0 & 28.0 & 0.0 & 0.0 & 0.0 & 0.1 & 0.0 & 1.1 \\
\hline 37 & Metal products & 3.6 & 38.9 & na & na & 3.3 & 43.4 & 4.5 & 45.0 \\
\hline 38 & Motor vehicles and parts & 5.2 & 18.9 & na & na & na & na & na & na \\
\hline 39 & Transport equipment n.e.c. & 3.0 & 28.4 & na & na & na & na & 2.8 & 28.3 \\
\hline 40 & Electronic equipment & 2.8 & 34.0 & 2.1 & 35.0 & na & na & 4.1 & 36.8 \\
\hline 41 & Machinery and equipment n.e.c. & 2.9 & 37.6 & 3.0 & 35.7 & 1.8 & 46.1 & 2.4 & 30.1 \\
\hline 42 & Manufactures n.e.c. & 3.8 & 46.7 & 5.0 & 47.7 & 5.6 & 39.7 & 13.1 & 40.9 \\
\hline & Total & 4.9 & 35.0 & 1.9 & 8.7 & 1.5 & 6.2 & 4.7 & 11.8 \\
\hline
\end{tabular}

Sources: Authors' calculations, UN Comtrade System, UNCTAD Trains Database

Note: In most cases, 'na' in the weighted averages means the absence of trade. Some 'na*' reflects 'specific' tariffs for which ad valorem equivalent tariff rates are not available in Arce and Taylor's dataset. 
The U.S. Tariff Schedule for the year 1997 was originally obtained from the UNCTAD TRAINS Database. Obtaining complete estimates of the tariff changes was hampered by the presence of 'specific' tariff rates. At the 8-digit level, 2,277 tariff lines out of 10,102 (or 22.5 percent of total tariff lines) are specific tariffs or combinations of specific and ad valorem rates. When specific tariffs apply, the ad valorem tariff equivalents, which were computed by Arce and Taylor (1997) for U.S. imports from China were used as a proxy. ${ }^{7}$ The trade-weighted averages were computed using the U.S. import data from Vietnam taken from the UN COMTRADE System. The aggregation was undertaken from the 6-digit level which is the most disaggregated level available in the COMTRADE System. The ad valorem tariff equivalents of MFN and non-MFN rates cover almost the entire list (99.9 percent) of U.S. imports from Vietnam in 1996. A serious problem evident from Table 2 is the absence of trade in a number of commodities, particularly where the unweighted average tariff rates are relatively high. This suggests that Vietnam faces prohibitive tariffs on certain commodities. In this situation, the weighted average tariff is very misleading-indicating zero protection when the protection rate is effectively infinitely high.

Given these caveats, the general rates are typically much higher than the MFN rates. The simple-average MFN duty rate of 1997 U.S. Tariff Schedule is 4.9 percent as against 35.0 percent for the non-MFN rate. The average tariff rates weighted by U.S.

\footnotetext{
${ }^{7}$ Arce and Taylor (1997) estimated the effects of the U.S. not renewing MFN status for imports from China. They constructed the ad valorem equivalents of specific or combination rates of the U.S. tariff schedule at the 10-digit level using the U.S. customs data on the value and quantity of imports. Their dataset covers 99.4 percent of U.S. imports from China. In 1995, the average trade-weighted MFN duty rate applied to U.S. imports from China was approximately 6 percent. Under the non-MFN rates, the trade-weighted tariff rate would rise to 44 percent. If China's MFN status were rescinded, their simulation result revealed that Chinese exports to the U.S. drop by approximately $\$ 11$ billion, or over 50 percent.
} 
imports from Vietnam differ substantially between years. The trade-weighted averages were 8.7 percent in 1994 and 6.2 percent in 1995 which were 6.8 point and 4.7 point higher than MFN rates respectively. In 1996, however, the weighted average had risen to 11.8 percent implying that Vietnam's composition of exports had shifted towards commodities with higher tariffs. The difference between MFN and non-MFN rates was 7.1 percentage points in 1996.

Table 3 compares Vietnam's exports to the EU15, Japan, and the U.S. by GTAP4 categories for the year 1996. Despite the recent increases in Vietnam's exports to the US, the US share of 4.8 percent was clearly low relative to the EU15's share of 24.0 percent and Japan's share of 28.7 percent. While Vietnam's exports of 'crops n.e.c.' (category 8) of $\$ 119$ million were significant, this was attributable mainly to coffee for which the tariff rate was already zero. In contrast, Vietnam's exports of 'wearing apparel' to the United States were very small. While Vietnam's exports of 'wearing apparel' to the EU15 ${ }^{8}$ and Japan were $\$ 456$ million and $\$ 489$ million respectively, exports to the U.S. accounted for only $\$ 26$ million in 1996.

\footnotetext{
${ }^{8}$ Vietnam signed a preferential trade agreement with the EU in 1992. This involved the granting of quotas to export textiles and clothing to Europe and the granting of a 2 percentage point preference on imports of selected items under over 200 tariff lines falling chapters 51-63 of the HS tariff schedule (Centre for International Economics, 1998).
} 
Table 3 - Vietnam's exports to the EU15, U.S. and Japan in 1996

\begin{tabular}{|c|c|c|c|c|c|c|}
\hline & EU15 & Share & JAPAN & Share & USA & Share \\
\hline & (US\$1,000) & $(\%)$ & (US\$1,000) & $(\%)$ & (US\$1,000) & $(\%)$ \\
\hline 1 Paddy rice & 752 & 0.0 & 89 & 0.0 & 0 & 0.0 \\
\hline 2 Wheat & 0 & 0.0 & 0 & 0.0 & 0 & 0.0 \\
\hline 3 Cereal grains & 1 & 0.0 & 230 & 0.0 & 51 & 0.0 \\
\hline 4 Vegetables, fruits, nuts & 4809 & 0.3 & 2026 & 0.1 & 8276 & 2.5 \\
\hline 5 Oil seeds & 102 & 0.0 & 1301 & 0.1 & 2 & 0.0 \\
\hline 6 Sugar cane, sugar beet & 1 & 0.0 & 0 & 0.0 & 14 & 0.0 \\
\hline 7 Plant-based fibers & 176 & 0.0 & 0 & 0.0 & 7 & 0.0 \\
\hline 8 Crops n.e.c. & 171038 & 10.1 & 40941 & 2.0 & 119436 & 35.4 \\
\hline 9 Bovine cattle, sheep, goats, horses & 0 & 0.0 & 0 & 0.0 & 0 & 0.0 \\
\hline 10 Animal products n.e.c. & 4500 & 0.3 & 6802 & 0.3 & 2782 & 0.8 \\
\hline 12 Wool, silk-worm cocoons & 0 & 0.0 & 54 & 0.0 & 0 & 0.0 \\
\hline 13 Forestry & 1704 & 0.1 & 3503 & 0.2 & 42 & 0.0 \\
\hline 14 Fishing & 430 & 0.0 & 7252 & 0.4 & 213 & 0.1 \\
\hline 15 Coal & 19215 & 1.1 & 69041 & 3.4 & 0 & 0.0 \\
\hline 16 Oil & 0 & 0.0 & 635430 & 31.6 & 85834 & 25.4 \\
\hline 18 Minerals n.e.c. & 19886 & 1.2 & 6094 & 0.3 & 36 & 0.0 \\
\hline 19 Bovine cattle, sheep and goat, horse meat & 1 & 0.0 & 0 & 0.0 & 0 & 0.0 \\
\hline 20 Meat products n.e.c. & 2 & 0.0 & 1004 & 0.0 & 0 & 0.0 \\
\hline 21 Vegetable oils and fats & 60 & 0.0 & 2077 & 0.1 & 0 & 0.0 \\
\hline 22 Dairy products & 0 & 0.0 & 0 & 0.0 & 0 & 0.0 \\
\hline 23 Processed rice & 9 & 0.0 & 47 & 0.0 & 6568 & 1.9 \\
\hline 24 Sugar & 0 & 0.0 & 0 & 0.0 & 0 & 0.0 \\
\hline 25 Food products n.e.c. & 40933 & 2.4 & 393598 & 19.6 & 39574 & 11.7 \\
\hline 26 Beverage and tobacco products & 175 & 0.0 & 4150 & 0.2 & 591 & 0.2 \\
\hline 27 Textiles & 14760 & 0.9 & 94429 & 4.7 & 182 & 0.1 \\
\hline 28 Wearing apparel & 456693 & 27.1 & 488580 & 24.3 & 25567 & 7.6 \\
\hline 29 Leather products & 310299 & 18.4 & 72367 & 3.6 & 11746 & 3.5 \\
\hline 30 Wood products & 76998 & 4.6 & 81493 & 4.1 & 1081 & 0.3 \\
\hline 31 Paper products, publishing & 929 & 0.1 & 4962 & 0.2 & 11 & 0.0 \\
\hline 32. Petroleum, coal products & 1 & 0.0 & 0 & 0.0 & 0 & 0.0 \\
\hline 33 Chemical, rubber, plastic, products & 339162 & 20.1 & 43148 & 2.1 & 31863 & 9.4 \\
\hline 34 Mineral products n.e.c. & 39842 & 2.4 & 6981 & 0.3 & 1319 & 0.4 \\
\hline 35 Ferrous metals & 34 & 0.0 & 1185 & 0.1 & 0 & 0.0 \\
\hline 36 Metals n.e.c. & 1598 & 0.1 & 2132 & 0.1 & 61 & 0.0 \\
\hline 37 Metal products & 3115 & 0.2 & 4674 & 0.2 & 97 & 0.0 \\
\hline 38 Motor vehicles and parts & 75 & 0.0 & 342 & 0.0 & 0 & 0.0 \\
\hline 39 Transport equipment n.e.c. & 3060 & 0.2 & 590 & 0.0 & 19 & 0.0 \\
\hline 40 Electronic equipment & 5336 & 0.3 & 7086 & 0.4 & 154 & 0.0 \\
\hline 41 Machinery and equipment n.e.c. & 8037 & 0.5 & 18052 & 0.9 & 325 & 0.1 \\
\hline 42 Manufactures n.e.c. & 162582 & 9.6 & 11611 & 0.6 & 1602 & 0.5 \\
\hline Total & 1686316 & 100.0 & 2011272 & 100.0 & 337451 & 100.0 \\
\hline Share (\%) & 24.0 & & 28.7 & & 4.8 & \\
\hline
\end{tabular}

Source: UN Comtrade System 1996;World Development Indicators 1988. 


\section{Analysis and Results}

\section{Theory of tariff liberalization by a trading partner}

The GTAP model used in the analysis is a comprehensive multi-region, multicommodity general equilibrium model incorporating global production, consumption, trade and policy distortions. Despite the resulting complexity of the model, the key features of the model results can be understood in terms of relatively simple partial equilibrium diagrams (Martin 1997)

The reduction in the US tariff on exports from Vietnam shifts the demand curve for exports from Vietnam to the right, as is shown in Figure 1. The result is an increase in both the volume of exports from Vietnam to the United States, and an increase in the price received for these exports. The resulting increase in the price of exports to the United States creates potentially substantial welfare benefits to Vietnam, measured in Figure 1 by area $p_{1} a b p_{0}$.

Figure 1 - Impacts of a reduction in the tariff on Vietnam's exports to the USA

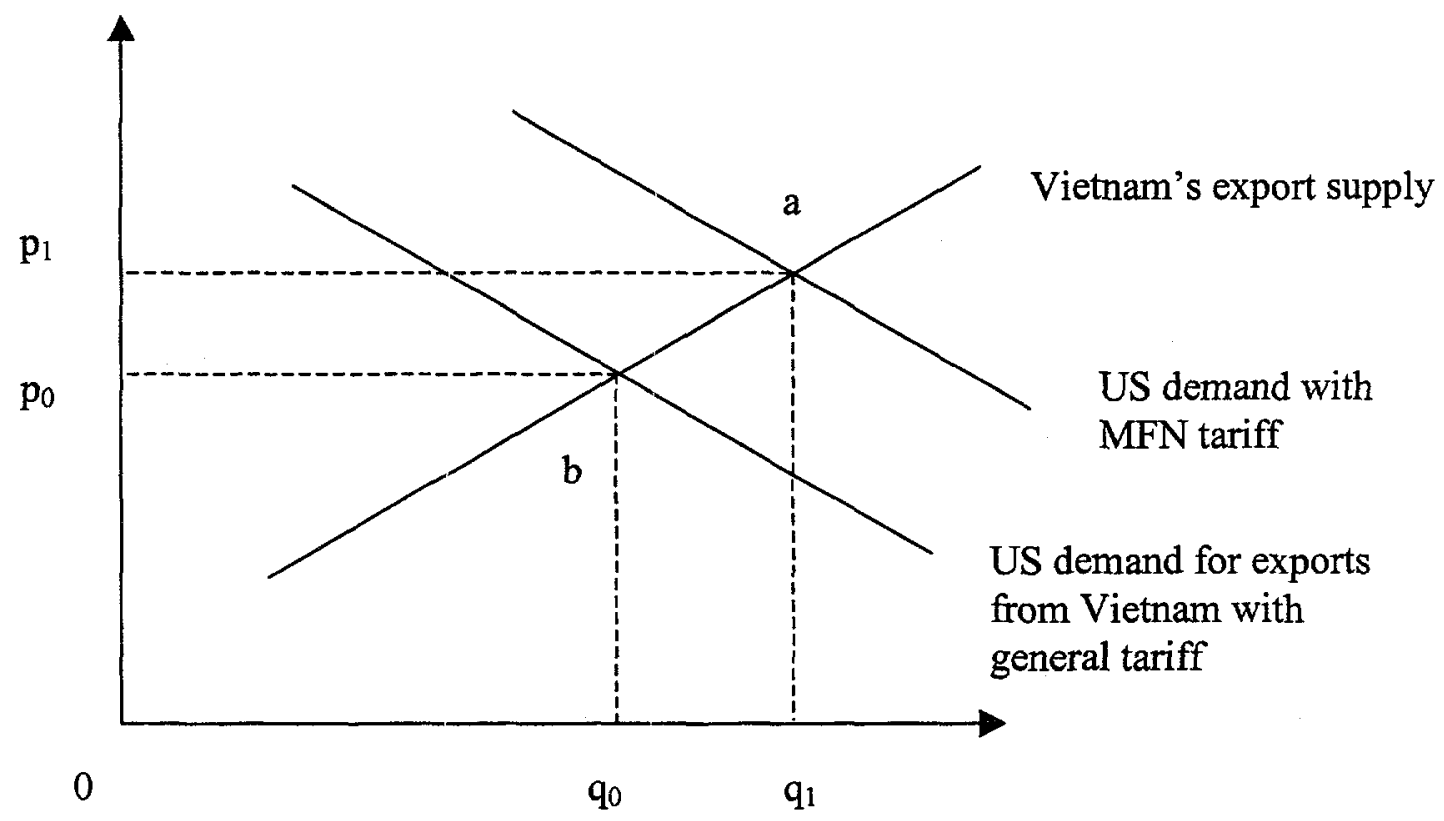


Because of the extensive distortions inherent in Vietnam's current trade regime, there are likely to be some other welfare changes resulting from increases or reductions in the volume of exports crossing trade barriers (see Martin 1997 for an interpretation of these second-best welfare impacts). If, for instance, the change in export market opportunities results in an increase in the volume of imports subject to distortions, there will be an increase in welfare because each unit of imports costs less on world markets than its value to users behind the tariff wall. In Figure 2, this effect is represented by the shift in the import demand curve for imports from partner countries from $D_{0}$ to $D_{1}$, and the consequent gain in welfare is shown by the shaded area abdc. As is clear from Figure 2 , the welfare benefits resulting from these additional imports will accrue as increases in tariff revenues, which may generate additional welfare benefits if they allow the government to reduce its dependence on other distorting taxes (Anderson and Martin 1998).

Figure 2. Impacts on import volumes passing across tariff barriers

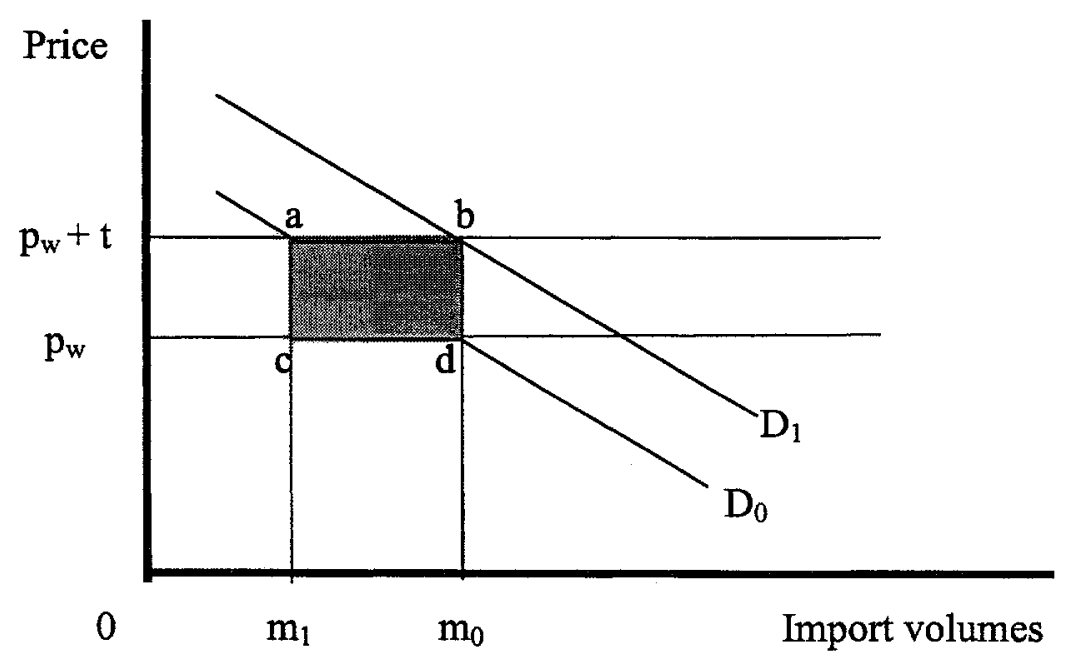


When access to the US market increases, there are likely to be increases in Vietnam's import demands for several reasons. Firstly, the increases in prices for goods that benefit from increased market access are likely to cause domestic consumers to substitute towards imported goods. Similarly, domestic users of intermediate inputs are likely to substitute to now relatively cheaper imported inputs. Domestic producers increasing their export production will also increase their volumes of imported inputs, although this may be offset by reductions in the volumes of inputs imported by other, contracting, sector-- the ultimate impact of these output changes will depend upon the relative import intensities of the expanding and contracting sectors. Finally, there will be changes in the volumes of imports resulting from changes in real incomes. While there is some controversy in the literature as to whether these should be included in measurements of welfare (Anderson and Martin 1996), they are included in the moneymetric measures of the type used in the GTAP model.

To capture all of these impacts requires a fully specified general equilibrium model and we use the GTAP global general equilibrium model to capture the needed interactions between actors and sectors.

\section{Model Structure}

The Global Trade Analyses (GTAP) model is a relatively standard static multisector multi-region Applied General Equilibrium (AGE) model documented comprehensively in Hertel (1997), with updated information on the GTAP web site. ${ }^{9}$ The model assumes that firms use constant returns to scale technology in perfectly 
competitive product market. Household consumption behavior is represented by a constant demand elasticity (CDE) expenditure function, while consumption and government demand are characterized by constant value shares. The equilibrium levels of production and consumption are determined by global demand and supply of the product and zero economic profit for firms. Traded goods are linked through international trade and classified by country of origin using the standard Armington assumption.

The version of the model used in this analysis is based on the Version 4 GTAP database. The base year of this data set is 1995 . However, because of the rapid changes in Vietnam's exports to the United States following the removal of the trade embargo, the database was modified to reflect the value and the composition of Vietnam's exports to the United States in 1996. This is important both for updates the model and to reduce the number of zero entries for Vietnam's exports to the USA. ${ }^{10}$ The simulation was conduced by reducing U.S. tariffs against imports from Vietnam from their 1996 nonMFN weighted average level to the MFN level.

${ }^{9}$ www.agecon.purdue.edu/gtap

${ }^{10}$ Models of this type work in percentage changes and are unable to move from zero levels of trade to nonzero levels. 


\section{Results of the Experiment}

Table 4 shows the changes in Vietnam's exports to the United States and to the world.

Tabie 4 - Changes in Vietnam's Exports

\begin{tabular}{|c|c|c|c|c|}
\hline & \multicolumn{2}{|c|}{ Value Changes } & \multicolumn{2}{|c|}{ Percentage Changes } \\
\hline & Exports to & Exports to & Exports to & Exports to \\
\hline & U.S. & the World & $\underline{\text { U.S. }}$. & the World \\
\hline & (\$ mil.) & (\$ mil.) & $(\%)$ & $(\%)$ \\
\hline AGR Agriculture and forestry & -2 & -31 & -1 & -3 \\
\hline PAG Processed agriculture & 10 & -21 & 19 & -2 \\
\hline BTP Beverage and tobacco & 1 & 1 & 125 & 18 \\
\hline COG Coal, oil, gas & 3 & -5 & 4 & 0 \\
\hline TEX Textiles & 0.4 & -4 & 241 & -2 \\
\hline CLO Clothing & 384 & 332 & 1512 & 38 \\
\hline LMF Light Manufacturing & 23 & -28 & 147 & -3 \\
\hline BMF Basic manufacturing & 4 & -1 & 329 & -1 \\
\hline CRP Chemical, rubber, plastics & 12 & 11 & 64 & 14 \\
\hline MCE Electronics and machinery & 1 & -2 & 284 & -3 \\
\hline Total & 430 & 250 & & \\
\hline
\end{tabular}

Source: Authors' Simulation Result

The first two columns present the changes in export values. The second two columns show the percentage changes in value which in turn reflect both quantity and price changes. The results suggest that Vietnam's exports to the United States would more than double following the granting of MFN status, increasing from the 1996 baseline level of $\$ 337.5$ million to $\$ 767.5$ million. ${ }^{11}$ The increase in exports of clothing is particularly significant, registering almost a fifteen-fold increase relative to the baseline. (Annex 4 reviews the current U.S. imports of textiles and apparel in some detail. For the recent Cambodia's experience, see Box 1). This estimated increase takes

11 In an earlier version of this paper and in Vietnam: Rising to the challenge (World Bank, 1998b), the effects of granting MFN status were estimated to be even larger than in the current paper. This is because we did not have estimates of the tariff equivalent of 'specific' tariffs when preparing the first paper, and excluded these commodities from the calculation of the average tariff. When these tariff equivalents became available, we found that the tariffs on these commodities (e.g. oil) were relatively low. Their inclusion therefore reduced our estimates of the average tariffs applied, and hence the trade-expanding effects of liberalization. On the other hand, since Vietnam's exports to the United States have been growing rapidly, the magnitude of the trade- 
into account only the reduction in tariff rates on these goods. Whether such a large increase could actually be realized would depend upon the arrangements made for phasing out of the MFA quota regime against these exports (Riedel, 1993). Because Vietnam is not a contracting party to the GATT 1947, the abolition of these quotas is not assured even if Vietnam becomes a member of the WTO.

\section{Box 1. The Effects of the United States Granting MFN Status - Cambodia's Experience}

Despite the political events in July 1997 and the Asian financial crisis, Cambodia managed to achieve a 33 percent increase in its exports in 1997. This remarkable development owed greatly to the United States granting Most Favored Nation (MFN) status to Cambodia on September 25, 1996. Since then, Cambodia's merchandise exports to the United States have increased rapidly, from 4.2 million in 1996, to 102.9 million in 1997 and 134.3 million in 1998. While the United States represented only 4 percent in Cambodia's total exports in 1996, its share increased to 21 percent in 1998.

The substantial increase in Cambodia's exports is mostly attributed to the clothing sector. The exports of this sector increased from \$2.3 million in 1996 to \$98.7 million in 1997. In 1998, Cambodia's exports of this category registered $\$ 130.2$ million or 97 percent of its total exports to the United States. This development was induced by the substantial tariff cuts against Cambodia's garment exports, from a simple average of 69.2 percent under the general rate to 12.8 percent under MFN rates.

The increase in the production of clothing in recent years has resulted in a dramatic increase in Cambodia's imports of textiles. Since 1996, Cambodia's imports of textiles have risen from \$61 million in 1996 to $\$ 117$ million in 1997, and \$247 million in 1998 .

The increased market access to the United States attracted more foreign investors ${ }^{12}$ mainly from Hong Kong, Taiwan, Malaysia, South Korea and Singapore. It is estimated that around 270 garment factories are now operating in Cambodia up from only 70 factories in 1997 (Reuters, Cambodia News, July 20).

Cambodia is likely to have difficulty achieving such high rates of growth in these products in the US market in the future, since the U.S. has imposed quotas on its main clothing exports. The growth rate of these quotas depends heavily upon the results of an annual, unilateral determination by the United States of whether Cambodia is protecting core labor standards. If the results are affirmative, the growth rates are quite high, at 14 percent per year, while they may withdraw such an increase if the US decides that labor standards are not being adequately protected.

Unfortunately, the ability of the importing countries to impose quotas has, if anything, been increased by the change by the move from the Multifibre Arrangement (MFA) MFA to the Agreement on Textiles and Clothing (ATC). While Article 3 of the MFA required that the exports from an individual

expansion may be larger by the time Vietnam obtains MFN. For instance, if the estimate is based on 1998 values, the increase in exports would have been around $\$ 750$ million per year.

${ }^{12}$ The nature of the model applied to Vietnam in this paper is static, and the total stock of capital is fixed. Thus, our model does not capture the effects of increased foreign direct investments (FDI) following the U.S. granting MFN treatment to Vietnam. 
supplier should be causing market disruption before quotas could be imposed, Article 6 of the ATC allows quotas to be imposed when total imports are causing market disruption. For small suppliers such as Cambodia, this change is particularly unfortunate.

The increase in exports to the U.S. of beverages and tobacco (BTP), textiles (TEX), basic manufacturing (BMF), and electronics and machinery (MCE) are significant in percentage changes, but negligible in value terms, reflecting the very low initial levels of these exports (see Figure 1). Exports of agriculture and forestry (AGR) decrease slightly by 1 percent from the baseline. This is because the non-MFN tariff rates of the main agricultural exports such as coffee and shrimps are already zero (Annex 3) implying that these industries benefit relatively less from the MFN status than the other sectors. It is likely that a certain amount of unskilled labor would shift from the agricultural sector to other labor intensive manufacturing sectors. The overall increases in Vietnam's exports of $\$ 250$ million are less than the increase in exports to the U.S., reflecting the shift in exports from other markets to the U.S. From the point of view of the United States, this experiment involves unwinding the trade diversion away from Vietnamese imports resulting from the higher tariff rate against imports from Vietnam.

Table 5 reports the changes in output by sector in Vietnam and the United States.

Table 5 - Changes in Output

\begin{tabular}{|llcc|}
\hline & $\frac{\text { Vietnam }}{(\%)}$ & $\frac{\text { USA }}{(\%)}$ \\
AGR & Agriculture and forestry & -0.7 & 0 \\
BMF & Basic manufacturing & -2 & 0 \\
BTP & Beverage and tobacco & -1.2 & 0 \\
CLO & Apparel & 31 & -0.1 \\
COG & Coal, oil, gas & -0.5 & 0 \\
CRP & Chemical, rubber, plastics & 2 & 0 \\
LMF & Light manufacturing & -3 & 0 \\
MCE & Electronics and machinery & -2 & 0 \\
PAG & Processed agriculture & -2 & 0 \\
\hline
\end{tabular}




\begin{tabular}{|llcc|}
\hline PCP & Petroleum products & -0.1 & 0 \\
TEX & Textiles & 7 & -0.03 \\
TRP & Transport equipment & -4.3 & 0.01 \\
\hline
\end{tabular}

Source: Authors' Simulation Results

The increase in production of clothing (CLO) by 31 percent is the mirror image of the increase in exports from this industry. The increase in production of textiles (TEX) follows from the increase in demand for textiles as inputs into the clothing industry. The increase in production of chemical, rubber and plastics products (CRP) appears to reflect an increase in the production of casual footwear. The production in other sectors decreases slightly since the domestic resources have been diverted into now more profitable sectors such as clothing. The output of clothing in the United States decreases by only 0.1 percent, and the overall impact on U.S. production patterns is negligible relative to the U.S. size of the economy.

Table 6 shows the key results for a range of economy-wide variables. In order to test the sensitivity of the model to the key parameters, the experiments were conducted using the standard Armington parameters (first two columns), decreasing the parameters by 50 percent (second two columns), and increasing them by 50 percent (third two columns). ${ }^{13}$

\footnotetext{
${ }^{13}$ We increased (decreased) the elasticities of substitutions between domestic products and imports as well as those between import sources by 50 percent.
} 
Table 6 - Key Results of the U.S. Granting MFN Status for Vietnam

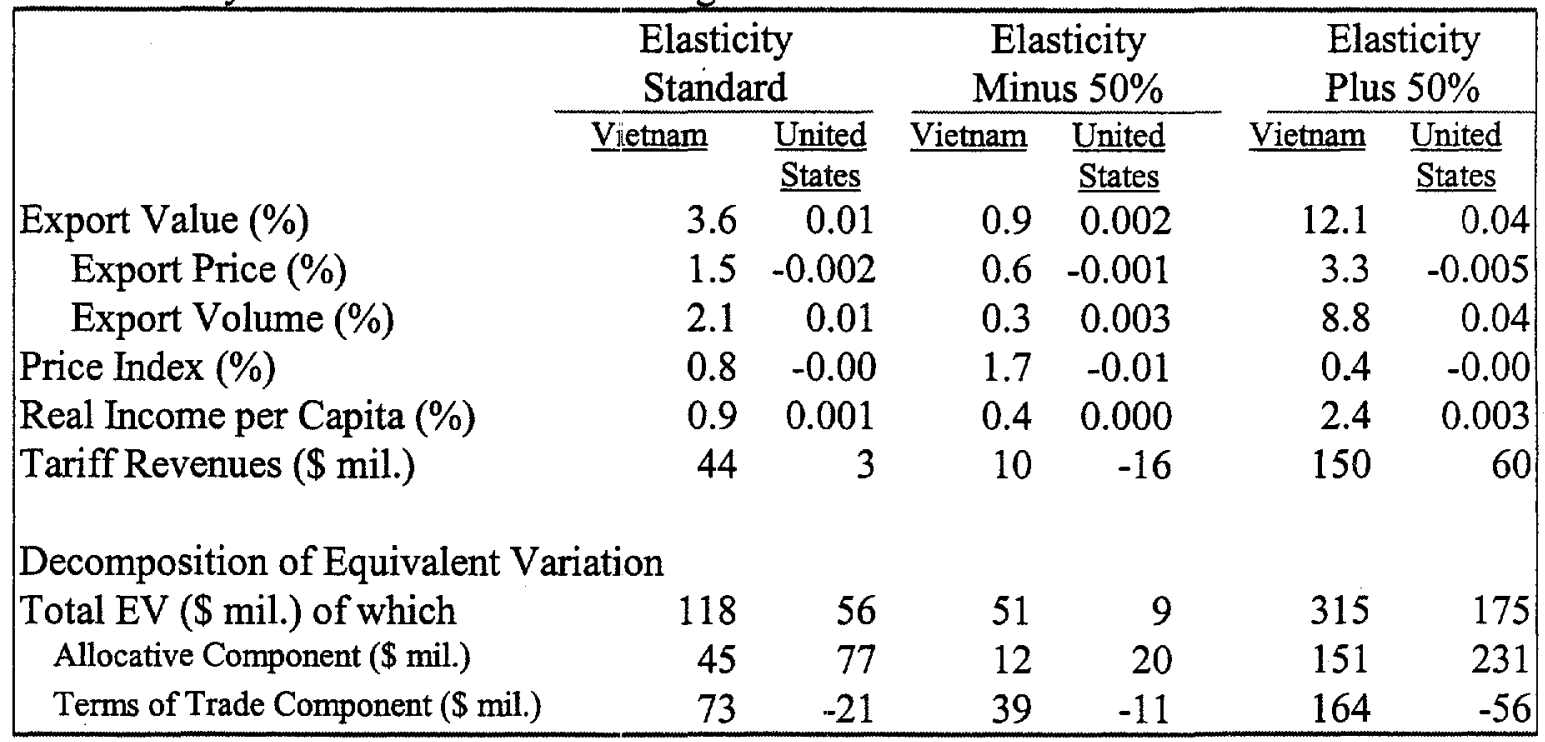

Source: Authors' Simulation Results

Following the grant of MFN status, Vietnam's export volume and terms of trade increase by 1.5 percent and 2.1 percent respectively. This in turn increases the total value of Vietnamese exports by 3.6 percent. As goods are redirected from the domestic market to export markets, the domestic consumer price rises by 0.8 percent. However, increased foreign exchange earnings from increased exports enable Vietnam to import more, and this in turn leads to an increase in tariff revenues of $\$ 44$ million. This increase in tariff revenues provides an indication of the second-best welfare gains from liberalization. It measures the difference between the value of the goods in the country and their value at the border, times the change in the quantity imported.

Overall, Vietnam's welfare measured by Equivalent Variation (EV) rises by $\$ 118$ million. Vietnam gains both from improved efficiency of resource allocation ( $\$ 45$ million) and from terms of trade gains ( $\$ 73$ million). This is about a 0.9 percent increase in real expenditure per capita. 
The effects of granting MFN treatment to Vietnam on the U.S. economy are relatively small. Overall, the welfare of the United States increases by $\$ 56$ million. Whereas the U.S. is positively affected by the improved resource allocation of $\$ 77$ million, the gains are partially offset by deterioration in the terms of trade of $\$ 21$ million as the USA increases its demand for imports from Vietnam.

\section{Caveats and Qualifications on the Results}

Sensitivity analysis on the Armington elasticities of substitution reported in Table 6 revealed that the results are sensitive to the values of these parameters. When the elasticities of substitution between domestic goods and imports and those between import sources are both increased by 50 percent, the change in EV increases by more than 50 percent. Gehlhar (1994) has shown that the standard elasticities used in the GTAP model, while derived from the best available econometric evidence, seem to be too low to capture the changes in trade patterns over time. Gehlhar found that it was necessary to roughly double the values of these elasticities if changes in trade patterns were to be captured. Based on the sensitivity results presented in Table 6, this would likely result in a welfare gain to Vietnam of over $\$ 400$ million per year.

Another reason to think that our estimates are conservative is examination of the estimated tariff rates. The non-MFN rates that we estimated using Vietnam's current pattern of exports to the USA are roughly a quarter of the average rates that Arce and Taylor's estimate would be applied against China in the absence of MFN (Arce and Taylor, 1997). Since Vietnam's current pattern of exports is strongly biased against the goods subject to high general tariff rates, the real rate of protection is much higher than 
the weighted average numbers would suggest - the prohibitive tariffs on many goods are assigned a zero weight. Since Vietnam's pattern of exports is very likely to evolve towards that of China, this higher rate is likely to be more representative in the longer term.

Further, the experiment considered focuses only on the impacts of actions by the United States. In reality, any decision by the United States to grant MFN arise from the ongoing bargaining process in which Vietnam is likely to make "concessions" that will increase the efficiency and competitiveness of its economy. Without knowledge of the size of the reductions in Vietnam's protection, it is unclear how large the consequent economic benefits are likely to be. However, past research (see, for example, Martin and Winters 1996; Bach, Lloyd and Martin 1999) suggests that the largest gains from reciprocal trade liberalization tend to accrue to the countries reducing their own barriers, rather than to those benefiting from reductions in the barriers they face in foreign markets.

\section{Conclusions}

In this paper, the direct impacts on Vietnam's trading opportunities of the US granting MFN treatment were first estimated by building up from the resulting level of tariffs applied to individual traded goods. Then, the economic impacts on Vietnam were inferred using simulations with the Global Trade Analysis (GTAP) model. The results revealed that the increased market access to the United States brings significant welfare gains to Vietnam. The direct terms of trade improvement resulting from increased market access accounts for 60 percent of the total gain, with the remaining 40 percent derived 
from second-best induced gains in efficiency. Exports to the United States more than double, from the 1996 baseline level of $\$ 337.5$ million to $\$ 767.5$ million. ${ }^{14}$ The estimated increase in exports of clothing is especially significant, with these exports increasing almost fifteen-fold while exports of agricultural commodities decrease slightly. Combined with the increased efficiency of allocation, the welfare measured by Equivalent Variation (EV) increases by $\$ 118$ million or 0.9 percent increase in real expenditure per capita. By granting MFN status for Vietnam, the United States also gains from improved resource allocation although some of the gains are offset by deterioration in its terms of trade. The gains for the United States were estimated to be around $\$ 56$ million per year.

The model results should be interpreted as extremely conservative, lower-bound, estimates of the benefits of MFN access to the United States. They are based on a purely static framework, on estimates of protection and trade elasticities that are very likely underestimated, and do not take into account the benefits of Vietnam's own liberalization. Even with these caveats, they point to substantial benefits to both Vietnam and the United States.

${ }^{14}$ As Vietnam's exports to the United States have been growing rapidly since the lifting of the embargo in 1994, the magnitude of the trade-expansion resulting from MFN status may be larger by the time Vietnam obtains MFN. Based on 1998 values, the increase in exports would have been around $\$ 750$ million per year. 


\section{References}

Anderson, J. M. and Martin, W. (1996), 'The welfare analysis of fiscal policy: a simple, unified account', Working Paper No 316, Department of Economics, Boston College (www.bc.edu).

Anderson, J. M. and Martin, W. (1998), 'Evaluating public expenditures when governments must rely on distortionary taxation', Policy Research Working Paper No 1981, World Bank, Washington DC (www.worldbank.org).

Arce, Hugh M. and Taylor, Christopher T. (1997), 'the Effects of Changing U.S. MFN Status for China,' Weltwirtschaftliches Archiv 1997, Vol. 133 (4): 737-753.

Bach, C., Lloyd, P.J. and Martin, W.(1999), 'The Uruguay Round, World Trade Organization, and Asia-Pacific Trade Liberalization', in Lloyd, P. J. ed. International Trade Opening and the Formation of the Global Economy, Edward Elgar, Cheltenham.

Centre for International Economics (1998), Vietnam's Trade Policies 1998, Canberra \& Sydney.

Gehlhar, M. (1997), 'Historical Analysis of Growth and Trade Patterns in the Pacific Rim: An Evaluation of the GTAP framework,' in Hertel, T. ed. Global Trade Analysis: Modeling and Applications, Cambridge University Press.

Hertel, T. (1997), Global Trade Analysis: Modeling and Applications, Cambridge University Press.

Martin, W. (1997), 'Measuring welfare changes with distortions' in Francois, J. and Reinert, K. eds. Applied Methods for Trade Policy Analysis: A Handbook, Cambridge University Press, C'ambridge.

Martin, W. and Winters, L. A. (1996), The Uruguay Round and the Developing Countries, Cambridge University Press, Cambridge.

Riedel, J. (1993), 'Vietnam: On the Trail of the Tigers,' World Economy, 16:401-22, July 1993.

U.S. Department of Commerce, Office of Textiles and Apparel (OTEXA) Web Site (http://otexa.ita.doc.gov)

World Bank (1998a), World Development Indicators 1998, Washington, D.C.

World Bank (1998b), Vietnam: Rising to the Challenge, An Economic Report of the World Bank Consultative Group for Vietnam, December 7-8, 1998. 
Annex 1. Vietnam's Exports to the United States 1994-1998

\begin{tabular}{|c|c|c|c|c|c|c|}
\hline GTAP & Description & 1994 & 1995 & 1996 & 1997 & 1998 \\
\hline 1 & Paddy rice & 0 & 0 & 0 & 0 & 0 \\
\hline 2 & Wheat & 0 & 0 & 0 & 0 & 0 \\
\hline 3 & Cereal grains & 0 & 0 & 51 & 260 & 159 \\
\hline 4 & Vegetables, fruits, nuts & 470 & 1223 & 8276 & 16092 & 23715 \\
\hline 5 & Oil seeds & 2 & 0 & 2 & 0 & 12 \\
\hline 6 & Sugar cane, sugar beet & 0 & 0 & 14 & 0 & 0 \\
\hline 7 & Plant-based fibers & 0 & 0 & 7 & 91 & 56 \\
\hline 8 & Crops n.e.c. & 32874 & 156067 & 119436 & 119133 & 159557 \\
\hline 9 & Bovine cattle, sheep, goats, horses & 0 & 0 & 0 & 0 & 0 \\
\hline 10 & Animal products n.e.c. & 203 & 394 & 2782 & 3773 & 8231 \\
\hline 12 & Wool, silk-worm cocoons & 0 & 0 & 0 & 0 & 0 \\
\hline 13 & Forestry & 0 & 0 & 42 & 0 & 30 \\
\hline 14 & Fishing & 30 & 189 & 213 & 378 & 3010 \\
\hline 15 & Coal & 1548 & 0 & 0 & 2795 & 0 \\
\hline 16 & Oil & 0 & 0 & 85834 & 37448 & 122018 \\
\hline 17 & Gas & 0 & 0 & 0 & 0 & 0 \\
\hline 18 & Minerals n.e.c. & 70 & 77 & 36 & 145 & 263 \\
\hline 19 & Bovine cattle, sheep, goat, horse meat & 0 & 0 & 0 & 0 & 0 \\
\hline 20 & Meat products n.e.c. & 0 & 0 & 0 & 0 & 0 \\
\hline 21 & Vegetable oils and fats & 1554 & 0 & 0 & 21 & 0 \\
\hline 22 & Dairy products & 0 & 0 & 0 & 0 & 22 \\
\hline 23 & Processed rice & 5339 & 8 & 6568 & 21862 & 0 \\
\hline 24 & Sugar & 0 & 0 & 0 & 1148 & 539 \\
\hline 25 & Food products n.e.c. & 6351 & 21507 & 39574 & 65270 & 103487 \\
\hline 26 & Beverage and tobacco products & 251 & 423 & 591 & 332 & 613 \\
\hline 27 & Textiles & 20 & 111 & 182 & 302 & 365 \\
\hline 28 & Wearing apparel & 2831 & 18317 & 25567 & 27914 & 30917 \\
\hline 29 & Leather products & 676 & 4197 & 11746 & 38474 & 49196 \\
\hline 30 & Wood products & 587 & 776 & 1081 & 1068 & 2164 \\
\hline 31 & Paper products, publishing & 47 & 30 & 11 & 120 & 84 \\
\hline 32 & Petroleum, coal products & 0 & 17 & 0 & 0 & 0 \\
\hline 33 & Chemical, rubber, plastic, products & 262 & 2388 & 31863 & 65550 & 75030 \\
\hline 34 & Mineral products n.e.c. & 316 & 796 & 1319 & 2072 & 4148 \\
\hline 35 & Ferrous metals & 0 & 0 & $\mathbf{0}$ & 0 & 22 \\
\hline 36 & Metals n.e.c. & 108 & 813 & 61 & 264 & 1535 \\
\hline 37 & Metal products & 0 & 9 & 97 & 221 & 924 \\
\hline 38 & Motor vehicles and parts & 0 & 0 & 0 & 0 & 52 \\
\hline 39 & Transport equipment n.e.c. & 0 & 0 & 19 & 6 & 49 \\
\hline 40 & Electronic equipment & 254 & 0 & 154 & 94 & 47 \\
\hline 41 & Machinery and equipment n.e.c. & 38 & 94 & 325 & 622 & 1582 \\
\hline 42 & Manufactures n.e.c. & 122 & 382 & 1602 & 1686 & 969 \\
\hline & Total & 53953 & 207817 & 337451 & 407139 & 588794 \\
\hline
\end{tabular}

Source: UN Comtrade System 


\section{Annex 2. Aggregation of the GTAP sectors used for Vietnam}

1. AGR(Agriculture and forestry)

1. paddy rice

2. wheat

3. cereal grains

4. vegetables, fruits, nuts

5. oil seeds

6. sugar cane

7. plant based fibers

8. crops n.e.c.

9. bovine cattle, sheep, goat, etc

10. animal products

12. wool, silk-worm, cocoons

13. forestry

14. fishing

\section{PAG(Processed agriculture)}

19. bovine, cattle etc meat

20 . meat products

21. vegetable oils \& fats

22 . daily products

23. processed rice

24. sugar

25. food products n.e.c.

3. BTP (Beverage and tobacco products)

26 . beverages $\&$ tobacco products

4. COG (Coal, oil, gas)

15. coal

16. oil

17. gas

18. minerals, n.e.c.

5. PCP (Refined Petroleum and coal products)

32. petroleum \& coal products

6. TEX (Textiles)
27. textiles

7. CLO(Apparel)

28. apparel

8. LMF(Light manufacturing)

29. leather products

30. wood products

42. manufactures n.e.c.

9. BMF(Basic manufacturing)

31. paper products, publishing

34. mineral products

35. ferrous metals

36. metal n.e.c.

37. metal products

10. CRP (Chemical, rubber, plastic products)

33. chemical, rubber, plastic products

11. TRP (Transport Equipment)

38. motor vehicles $\&$ parts

39. transport equipment n.e.c.

12. MCE (Electronics and Machinery)

40. electronic equipment

41. machinery \& equipment

13. OTH (Others)

43. electricity

44. gas manufacture, distribution

45. water

46. construction

47. trade, transport

48. financial business, recreational services

49. pubic administration and defense, education, health services

50.dwellings 
Annex 3A. Leading Vietnam's Export Commodities to the U.S. 1994

\begin{tabular}{|c|c|c|c|c|c|c|}
\hline & HS Code & Description & Imports & $\begin{array}{c}\begin{array}{c}\text { Share in Total } \\
\text { Exports }\end{array} \\
\end{array}$ & $\begin{array}{l}\text { Non-MFN } \\
\text { Tariff Rates }\end{array}$ & $\begin{array}{c}\text { MFN Tariff } \\
\text { Rates }\end{array}$ \\
\hline & & & (US\$1,000) & $(\%)$ & $(\%)$ & $(\%)$ \\
\hline 1 & 90111 & Coffee, not roasted or decaffeinated & 29017 & 53.8 & 0.0 & 0.0 \\
\hline 2 & 30613 & Frozen shrimps and prawns & 5352 & 9.9 & 0.0 & 0.0 \\
\hline 3 & 100630 & Semi-milled or wholly milled rice & 5339 & 9.9 & 35.0 & 8.8 \\
\hline 4 & 90112 & Decaffeinated coffee, not roasted & 2145 & 4.0 & 0.0 & 0.0 \\
\hline 5 & 620520 & Men's or boys' shirts of cotton & 1666 & 3.1 & 67.5 & 14.9 \\
\hline 6 & 151311 & Crude coconut (copra) oil and fractions & 1554 & 2.9 & n.a. & 0.0 \\
\hline 7 & 270111 & Anthracite, not agglomerated & 1548 & 2.9 & 0.0 & 0.0 \\
\hline 8 & 90240 & Black tea & 999 & 1.9 & 0.0 & 0.0 \\
\hline 9 & 621600 & Gloves, mittens and mitts & 986 & 1.8 & 37.2 & 11.0 \\
\hline 10 & 420292 & Containers with surface of plastic or textiles & 651 & 1.2 & 46.4 & 11.9 \\
\hline & & Total & 49257 & 91.3 & & \\
\hline
\end{tabular}

\section{Annex 3B. Leading Vietnam's Export Commodities to the U.S. 1995}

\begin{tabular}{|c|c|c|c|c|c|c|}
\hline & HS Code & Description & Imports & \begin{tabular}{|c|}
$\begin{array}{c}\text { Share in Total } \\
\text { Exports }\end{array}$ \\
\end{tabular} & $\begin{array}{l}\text { Non-MFN } \\
\text { Tariff Rates }\end{array}$ & $\begin{array}{c}\text { MFN Tariff } \\
\text { Rates } \\
\end{array}$ \\
\hline & & & (US\$1,000) & $(\%)$ & $(\%)$ & $(\%)$ \\
\hline 1 & 90111 & Coffee, not roasted or decaffeinated & 146025 & 70.3 & 0.0 & 0.0 \\
\hline 2 & 30613 & Frozen shrimps and prawns & 17067 & 8.2 & 0.0 & 0.0 \\
\hline 3 & 621600 & Gloves, mittens and mitts & 8212 & 4.0 & 37.2 & 11.0 \\
\hline 4 & 620520 & Men's or boys' shirts of cotton & 6899 & 3.3 & 67.5 & 14.9 \\
\hline 5 & 90112 & Decaffeinated coffee, not roasted & 5642 & 2.7 & 0.0 & 0.0 \\
\hline 6 & 640399 & Footwear with rubber soles, leather uppers & 3184 & 1.5 & 22.7 & 8.3 \\
\hline 7 & 330129 & Essential oils (incl. concretes and absolutes) & 1606 & 0.8 & 13.3 & 1.0 \\
\hline 8 & 180100 & Cocoa beans, whole or broken & 1408 & 0.7 & 0.0 & 0.0 \\
\hline 9 & 400122 & Technically specified natural rubber & 1279 & 0.6 & 0.0 & 0.0 \\
\hline 10 & 30420 & Frozen fish fillets & 1257 & 0.6 & 1.7 & 0.3 \\
\hline & & & 192579 & 92.7 & & . \\
\hline
\end{tabular}

Annex 3C. Leading Vietnam's Export Commodities to the U.S. 1996

\begin{tabular}{|c|c|c|c|c|c|c|}
\hline & HS Code & Description & Imports & $\begin{array}{c}\text { Share in Total } \\
\text { Exports }\end{array}$ & $\begin{array}{l}\text { Non-MFN } \\
\text { Tariff Rates }\end{array}$ & $\begin{array}{c}\text { MFN Tariff } \\
\text { Rates }\end{array}$ \\
\hline & & & (US\$1,000) & $(\%)$ & $(\%)$ & $(\%)$ \\
\hline 1 & 90111 & Coffee, not roasted or decaffeinated & 115708 & 34.3 & 0.0 & 0.0 \\
\hline 2 & 270900 & Petroleum oils & 85834 & 25.4 & 1.3 & 0.4 \\
\hline$\overline{3}$ & 30613 & Frozen shrimps and prawns & 28896 & 8.6 & 0.0 & 0.0 \\
\hline 4 & 640291 & Footwear covering the ankle of rubber, plastics & 12658 & 3.8 & 55.0 & 32.9 \\
\hline 5 & 640411 & Sports footwear,with rubber or plastic soles & 12463 & 3.7 & 57.2 & 34.5 \\
\hline 6 & 620520 & Men's or boys' shirts of cotton & 9477 & $\overline{2.8}$ & 67.5 & 14.9 \\
\hline 7 & 80130 & Cashew nuts, fresh or dried & 8015 & 2.4 & 0.9 & 0.0 \\
\hline 8 & 640399 & Footwear with rubber soles, leather uppers & 7899 & 2.3 & 22.7 & 8.3 \\
\hline 9 & 100630 & Semi-milled or wholly milled rice & 6568 & 1.9 & 35.0 & 8.8 \\
\hline 10 & 621600 & Gloves, mittens and mitts & 6014 & 1.8 & 37.2 & 11.0 \\
\hline & & & 293532 & 87.0 & & \\
\hline
\end{tabular}


Annex 3D. Leading Vietnam's Export Commodities to the U.S. 1997

\begin{tabular}{|r|r|l|r|r|r|r|}
\hline & HS Code & Description & Imports & $\begin{array}{c}\text { Share in Total } \\
\text { Exports }\end{array}$ & $\begin{array}{r}\text { Non-MFN } \\
\text { Tariff Rates }\end{array}$ & $\begin{array}{r}\text { MFN Tariff } \\
\text { Rates }\end{array}$ \\
\hline & & & (US\$1,000) & $(\%)$ & $(\%)$ & $(\%)$ \\
\hline 1 & 90111 & Coffee, not roasted or decaffeinated & 112033 & 27.5 & 0.0 & 0.0 \\
\hline 2 & 270900 & Petroleum oils & 37448 & 9.2 & 0.4 & 1.3 \\
\hline 3 & 640411 & Sports footwear, with rubber or plastic soles & 37411 & 9.2 & 34.5 & 57.4 \\
\hline 4 & 30613 & Frozen shrimps and prawns & 36109 & 8.9 & 0.0 & 0.0 \\
\hline 5 & 640399 & Footwear with rubber soles, leather uppers & 23401 & 5.7 & 8.3 & 22.7 \\
\hline 6 & 100630 & Semi-milled or wholly milled rice & 21588 & 5.3 & 8.8 & 35.0 \\
\hline 7 & 640299 & Footwear not covering the ankle, of rubber or plastics & 16663 & 4.1 & 25.9 & 48.7 \\
\hline 8 & 80130 & Cashew nuts, fresh or dried & 15984 & 3.9 & 0.0 & 0.9 \\
\hline 9 & 640391 & Footwear with rubber soles and leather uppers & 14417 & 3.5 & 7.8 & 20.0 \\
\hline 10 & 160520 & Shrimps and prawns, prepared or preserved & 10352 & 2.5 & 3.5 & 10.0 \\
\hline & & & 300637 & & 73.8 & \\
\hline
\end{tabular}

Annex 3E. Leading Vietnam's Export Commodities to the U.S. 1998

\begin{tabular}{|c|c|c|c|c|c|c|}
\hline & HS Code & Description & Imports & $\begin{array}{c}\text { Share in Total } \\
\text { Exports }\end{array}$ & $\begin{array}{c}\text { Non-MFN } \\
\text { Tariff Rates }\end{array}$ & $\begin{array}{c}\text { MFN Tariff } \\
\text { Rates }\end{array}$ \\
\hline & & & (US\$1,000) & $(\%)$ & $(\%)$ & $(\%)$ \\
\hline 1 & 90111 & Coffee, not roasted or decaffeinated & 147643 & 25.1 & 0.0 & 0.0 \\
\hline 2 & 270900 & Petroleum oils & 122018 & 20.7 & 0.4 & 1.3 \\
\hline 3 & 30613 & Frozen shrimps and prawns & 63296 & 10.8 & 0.0 & 0.0 \\
\hline 4 & 640299 & Footwear not covering the ankle, of rubber or plastics & 60826 & 10.3 & 25.9 & 48.7 \\
\hline 5 & 640399 & Footwear with rubber soles, leather uppers & 38714 & 6.6 & 8.3 & 22.7 \\
\hline 6 & 80130 & Cashew nuts, fresh or dried & 23494 & 4.0 & 0.0 & 0.9 \\
\hline 7 & 160520 & Shrimps and prawns, prepared or preserved & 13683 & 2.3 & 3.5 & 10.0 \\
\hline 8 & 620520 & Men's or boys' shirts of cotton & 9142 & 1.6 & 14.9 & 67.5 \\
\hline 9 & 640391 & Footwear with rubber soles and leather uppers & 8974 & 1.5 & 7.8 & 20.0 \\
\hline \multirow[t]{2}{*}{10} & 30420 & Frozen fish fillets & 8795 & 1.5 & 0.3 & 1.7 \\
\hline & & & 496584 & 84.3 & & \\
\hline
\end{tabular}

Source: UN Comtrade System 


\section{Annex 4. Textiles and Apparel Exports to the United States 1997}

The model results suggest that the clothing is the sector where Vietnam is likely to benefit the most from obtaining US MFN status. In 1997, the United States imported \$54.0 billion worth of textiles and apparel from the world of which $\$ 42.8$ billion were apparel imports. ${ }^{15}$ Table 4 a shows total imports of textiles and apparel and Table $4 \mathrm{~b}$ presents apparel only.

\begin{tabular}{|lrc|}
\hline \multicolumn{3}{|c|}{$\begin{array}{l}\text { Table 4a. Major Shippers of Textiles and Apparel } \\
1997\end{array}$} \\
\hline \multicolumn{1}{|c|}{ Country } & Imports(\$ mil.) & Share (\%) \\
\hline 1 Mexico & 5928 & 11.0 \\
2 China & 6024 & 11.2 \\
3 Hong Kong & 4100 & 7.6 \\
4 Taiwan & 2812 & 5.2 \\
5 Canada & 2401 & 4.4 \\
6 Korea & 2288 & 4.2 \\
7 Dominican Rep. & 2273 & 4.2 \\
8 India & 2010 & 3.7 \\
9 Indonesia & 1872 & 3.5 \\
10 Philippines & 1846 & 3.4 \\
11 Italy & 1846 & 3.4 \\
12 Honduras & 1663 & 3.1 \\
13 Thailand & 1661 & 3.1 \\
14 Bangladesh & 1499 & 2.8 \\
15 Sri Lanka & 1362 & 2.5 \\
16 Pakistan & 1197 & 2.2 \\
17 Salvador & 1079 & 2.0 \\
18 Guatemala & 971 & 1.8 \\
19 Vietnam & 26 & 0.05 \\
20 Others & 11145 & 20.6 \\
\hline World & 54002 & 100.0 \\
\hline
\end{tabular}

\begin{tabular}{|lrc|}
\hline \multicolumn{3}{|c|}{ Table 4b. Major Shippers of Apparel 1997 } \\
\hline \multicolumn{1}{|c|}{ Country } & Imports(\$ mil.) & Share (\%) \\
\hline 1 Mexico & 5050 & 11.8 \\
2 China & 4488 & 10.5 \\
3 Hong Kong & 3935 & 9.2 \\
4 Dominican Rep. & 2216 & 5.2 \\
5 China & 2071 & 4.8 \\
6 Honduras & 1659 & 3.9 \\
7 Indonesia & 1596 & 3.7 \\
8 Philippines & 1597 & 3.7 \\
9 Korea & 1518 & 3.5 \\
10 Bangladesh & 1448 & 3.4 \\
11 India & 1347 & 3.1 \\
12 Thailand & 1257 & 2.9 \\
13 Canada & 1204 & 2.8 \\
14 Sri Lanka & 1204 & 2.8 \\
15 Italy & 1226 & 2.9 \\
16 El Salvador & 1052 & 2.5 \\
17 Guatemala & 962 & 2.2 \\
18 Macau & 930 & 2.2 \\
19 Vietnam & 26 & 0.06 \\
20 Others & 672 & 1.6 \\
\hline World & 42827 & 100.0 \\
\hline
\end{tabular}

Source: the U.S. Department of Commerce

The U.S. primarily sourced textiles and apparel from NAFTA, Asian and Latin American countries in 1997. Mexico, China, and Hong-Kong were the leading suppliers both for total textiles and for apparel exports. Some countries' exports, including Canada, consist of non-apparel such as fabrics whereas some developing countries, including Vietnam, export almost exclusively apparel. This is at least partially due to the fact that textiles are more capital intensive than apparel, giving the low income countries a comparative advantage in the latter. The U.S. imported $\$ 26.4$ million worth of textiles and apparel from Vietnam in 1997 of which 98 percent belonged to apparel. Vietnam represented 0.05 percent of the market share in the United States.

Table 3c. (see 'table3c.xls') shows U.S. imports of apparel by 3-digit US MFA category. The statistics for China and Cambodia are also shown for the purpose of comparison. China exports a wide range of apparels to the U.S. registering 947 million metric equivalents ( $\$ 4.5$ billion in value). The United States granted MFN status to Cambodia on September 25, 1996. Cambodia's exports of textiles and apparel increased from 2.4 million M2 (\$2.3 million) in 1996 to 30.2 million M2 (\$98.7 million) in 1997. January-May figures in 1998 alone registered 32.0 million M2 (\$94.7 million).

${ }^{15}$ http://otexa.ita.doc.gov 


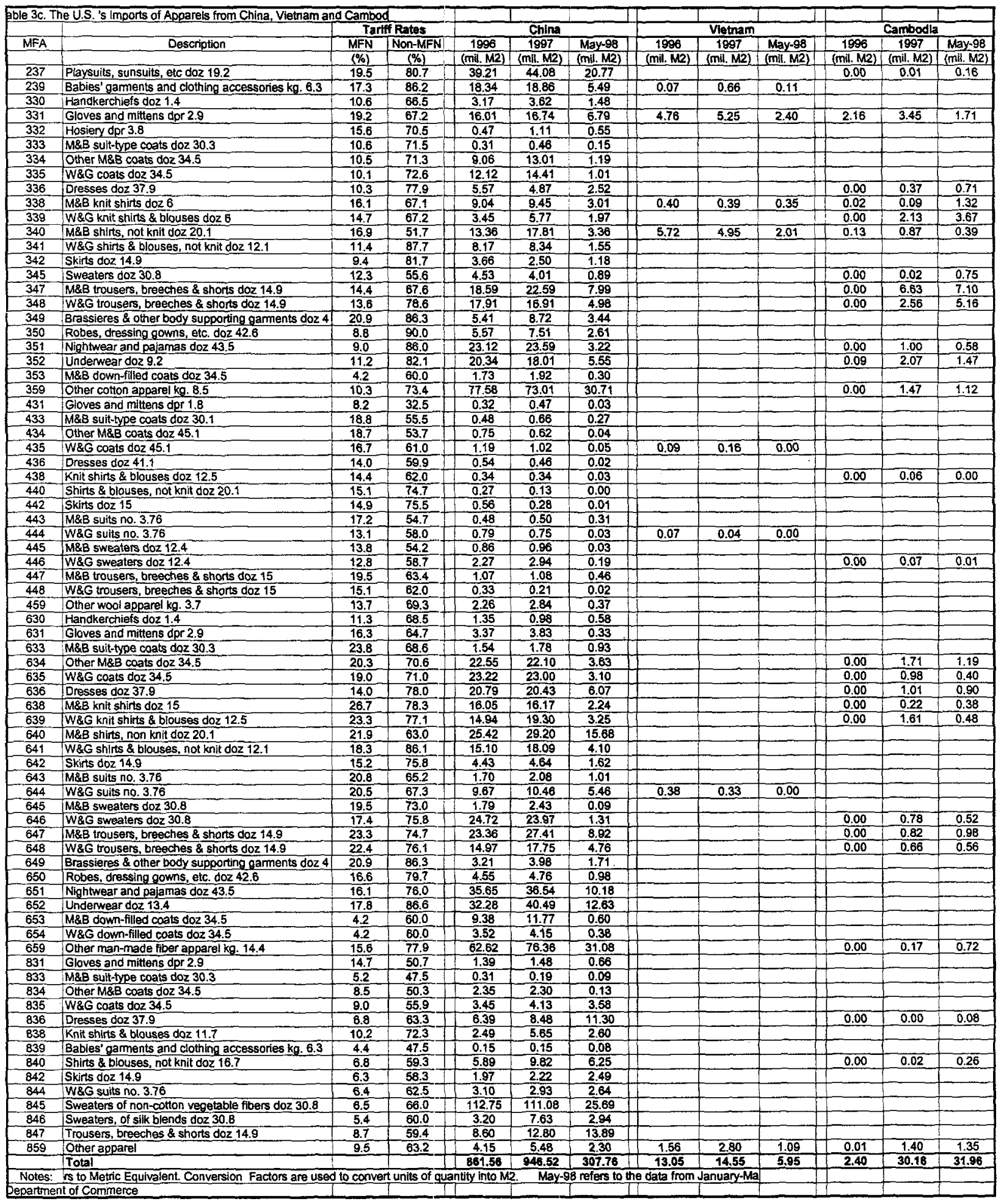




\section{Policy Research Working Paper Series}

Title

WPS2201 F

\section{Capital Accumulation}

WPS2202 Specialization without Regret:

Transfer Rights, Agricultural

Productivity, and Investment in an

Industrializing Economy

WPS2203 Market versus Administrative Reallocation of Agricultural Land in a Period of Rapid Industrialization

WPS2204 Corruption under Moral Hazard

WPS2205 Foreign-Owned Capital and Endogenous Tariffs

WPS2206 Household Childcare Choices and Women's Work Behavior in Russia

WPS2207 Jamaica's Food Stamp Program: Impacts on Poverty and Welfare

WPS2208 Ethnic Partition as a Solution to Ethnic War: An Empirical Critique of the Theoretical Literature

WPS2209 Does Corruption Relieve Foreign Investors of the Burden of Taxes and Capital Controis?

WPS2210 The Sliperry Slope: Explaining the Increase in Extreme Poverty in Urban Brazil, 1976-96

WPS2211 Competition Policy, Developing Countries, and the World Trade Organization

WPS2212 is African Manufacturing SkillConstrained?

WPS2213 Fiscal Solvency and Sustainability in Economic Management
Author

Michael R. Carter

Yang Yao

Michael R. Carter

Yang Yao

Gunnar S. Eskeland

Henrik Thiele

Marcelo Olarreaga

Michael M. Lokshin

Kene Ezemenari

Kalanidhi Subbarao

Nicholas Sambanis

October 1999

Shang-Jin Wei

Francisco H. G. Ferreira Ricardo Paes de Barros

Bernard Hoekman

Peter Holmes

Howard Pack

Christina Paxson

Hinh T. Dinh
Date

October 1999

October 1999

October 1999

October 1999

Contact for paper

E. Mekhova 85984

M. Fernandez 33766

M. Fernandez 33766

October 1999

H. Sladovich 37698

October 1999

L. Tabada 36896

October 1999

P. Sader 33902

October 1999

G. Peralta 37405

H. Sladovich 37698

H. Sladovich 37698

October 1999

G. llogon 33732

October 1999

L. Tabada 36896

October 1999

H. Sladovich 37698

October 1999 


\section{Policy Research Working Paper Series}

\begin{tabular}{|c|c|c|c|c|}
\hline & Title & Author & Date & $\begin{array}{l}\text { Contact } \\
\text { for paper }\end{array}$ \\
\hline WPS2214 & $\begin{array}{l}\text { Trade Policy and Market Access } \\
\text { Issues for Developing Countries: } \\
\text { Implications for the Millennium } \\
\text { Round }\end{array}$ & Constantine Michalopoulos & October 1999 & $\begin{array}{l}\text { L. Tabada } \\
36896\end{array}$ \\
\hline WPS2215 & $\begin{array}{l}\text { Implementation of Uruguay Round } \\
\text { Commitments: The Development } \\
\text { Challenge }\end{array}$ & $\begin{array}{l}\text { J. Michael Finger } \\
\text { Philip Schuler }\end{array}$ & October 1999 & $\begin{array}{l}\text { L. Tabada } \\
36896\end{array}$ \\
\hline WPS2216 & $\begin{array}{l}\text { Corruption and Trade Tariffs, or } \\
\text { a Case for Uniform Tariffs }\end{array}$ & Roberta Gatti & October 1999 & $\begin{array}{l}\text { R. Gatti } \\
38735\end{array}$ \\
\hline WPS2217 & $\begin{array}{l}\text { Border, Border, Wide and Far, } \\
\text { How We Wonder What You Are }\end{array}$ & $\begin{array}{l}\text { David C. Parsley } \\
\text { Shang-Jin Wei }\end{array}$ & November 1999 & $\begin{array}{l}\text { H. Sladovich } \\
37698\end{array}$ \\
\hline WPS2218 & $\begin{array}{l}\text { Who Avoids and Who Escapes } \\
\text { Poverty during the Transition: } \\
\text { Evidence from Polish Panel Data, } \\
\text { 1993-96 }\end{array}$ & Wlodzimierz Okrasa & November 1999 & $\begin{array}{l}\text { S. Fallon } \\
38009\end{array}$ \\
\hline
\end{tabular}

118 